\title{
Searching for Neurobiological Foundations of Faith and Religion
}

\section{Maria Weker}

The Cardinal Wyszyński University

in Warsaw,

Poland

e-mail: mariaweker@gmail.com

\begin{abstract}
:
Considering that the brain is involved in human thinking, feeling and behaviour, we must also ask the question of whether finding neural correlates of religious experience is not just a matter of time. The questions 'if' and 'how' human brain responds to or generates religious experience capture the interest of researchers from various fields of science. Their joint efforts and scientific discourse lead to implementation of bold interdisciplinary research projects, with a far-reaching goal of explaining the mystery of faith and religion. Studies conducted at the meeting point of empirical and theological sciences raise controversies and criticism. Examples include the discussions on natural and theological experiments, collectively called neurotheology.
\end{abstract}

Keywords: neurotheology, mind, brain, religion, religious experience, neurotheological experiments.

\section{Preliminary Remarks}

The term 'neurotheology' is applied to research and analyses aimed at identifying neuronal foundations of religious experience. Such activity is human-specific. Therefore, it is specific for humankind to create and profess certain beliefs and convictions included in myths and religions. Anthropologists agree that there are no human cultures without a mythology or religion [12], [8]. In recent years, researchers have focused also on specific behaviour of hominids (in particular in Homo Sapiens Neanderthalensis and Homo Heidelbergensis) which may indicate that they had religious or mythological beliefs about life and death. Cultural anthropologists argue that evidence for this hypothesis may be found i.a. in preserved grave sites, traces of decorating the dead with flowers, special burial sites and remains of special purpose constructions [11]. Therefore, searching for relevant and universal forms of brain and mental activity justifying such behaviour seems sanctioned in both scientific and cultural terms.

The term 'neurothology' was popularised by James Ashbrook, a theologian who studied neuroscience [1]. He believed it justified to rationalise the phenomenon of religious experience by describing and analysing with methods used in natural and psychological sciences, in particular 
those allowing to investigate human cognitive and brain activity. The aim of the research was to explain why humans need to have beliefs in the form of religions and myths.

It is worth noting that the term 'neurotheology' is applied to the majority of interdisciplinary studies and analyses which combine empirical methods of medical and neurobiological sciences and the study of religious experience. Neurotheology comprises the studies which use neuronal activity imagining, as well as genetic studies and projects from the field of molecular biology.

\section{Areas of Study}

Proponents of neurotheological approach believe that faith is related to human brain structure and its functioning patterns. Studies to confirm this hypothesis are conducted using various empirical methods that are specific to natural sciences. Research projects use neuroimaging methods (e.g. PET, SPECT, fMRI), techniques affecting the cortex activity (e.g. TMS), genetic and molecular research. Interestingly, those projects are interlinked and build on earlier research results and their interpretation.

The fundamental proposition behind neurotheological projects is that religious experience is linked to the functioning of human brain. The resulting assumption is that the study of human brain activity allows to identify such forms of brain structure activity which are specific and exclusive for religious experience, and to determine their parameters. Therefore, it is possible to obtain information on its intensity, course, nature and location in brain structures. Those hypotheses were of key importance for research aimed at analysing brain activity during religious experience, i.e. prayer, meditation and open or concealed manifestation of religious beliefs and faith. Those preassumptions also determined the experiments focusing on investigation of artificially induced sensations similar to religious the religious ones.

Such studies were conducted in the 1980s by Michael Persinger et al. Building on medical theories pointing to the link between brain functioning distortions and experienced consciousness disturbances, Persinger assumed that specific sensations may be artificially evoked. He based his assumptions on observations of altered states of consciousness occurring in e.g. epileptic attacks [16]. Persinger also took into account the fact that brain function disorders may be caused by physiological factors (oxygen deficiency, malnutrition, inappropriate arousals caused by trauma or disease, etc.), chemical factors (pharmacological agents, psychedelic drugs, etc.) or by using the devices stimulating specific brain areas electrically or magnetically. This last fact was used by the Persinger's team to build the essential device for their experiment. It was a type of helmet with appropriately placed solenoids generating magnetic field. When put on the head of a volunteer and activated, it caused temporary disturbance in the cortex activity in frontal, temporal and occipital lobes. Brain activity was monitored with EEG. The device, also called the God helmet, was tested on 600 volunteers who were also asked to fill in a questionnaire. The analysis of EEG readings, subjective and individual description of experiences and information obtained from the tests revealed that over $80 \%$ of the volunteers reported sensations described as non-empirical and mystical, and corresponding to their religious beliefs [15], [19]. At the beginning of the $21^{\text {st }}$ century, a similar study consisting in eliciting specific states of consciousness by disturbing the brain field activity was conducted by a team headed by Peter Granqvist who, however, obtained different results [14].

Andrew Newberg et al analysed brain activity during the performance of religious activities using the SPECT (single-photon emission computed tomography) neuroimaging technique, which allows to measure the level of metabolism and blood flow in specific parts of the body. Further research included scanning of the brains of several dozen people who prayed and meditated, achieving the state that they described as 'onesness with the universe'. When the subjects achieved the sense of unity with the Absolute/God, scans were taken that presented the fields of brain activity [14], [7]. The studies using the PET (positron emission tomography) technique were performed by Nina P. Azari et al. Religious and non-religious volunteers read the same excerpts from the Bible, fragments of neutral texts and recited child verse, while their brains were scanned. The scans 
revealed that different regions of the brain were activated, depending on the type of text [2], [7]. Similar studies were conducted by Mario Beauregard and Vincent Paquette who analysed brain activity using EEG and fMRI. Volunteers (Carmelite nuns) had their brains scanned when recalling 'mystical states' occurring during deep meditation and prayer. The records were compared with the resting state brain activity [4]. Other similar studies include research by Vilayanur Subramanian Ramachandran, who measured galvanic skin responses to various images, including religious ones, in patients suffering from temporal lobe epilepsy. Religious images elicited particularly high responses in volunteers, which was interpreted as the confirmation of correlation between sensitivity and susceptibility to religious images and activity of temporal lobes [18].

Another group of studies comprises biological and molecular research, the aim of which is to i.a. search for genes responsible for generating specific religious attitudes. Such studies were conducted i.a. by behavioural geneticist Dean Hammer. According to him, acceptance of the hypothesis of neuronal foundations of faith requires determination of whether the process is genetically programmed and whether there are genes responsible for this phenomenon. Their presence would not only be an argument in favour of uniqueness of the humankind, but would also justify the special need of humans to perform religious rituals [10]. Hammer used the reports of mental sensations occurring during mystic experiences as his starting point. He focused on 'out-ofbody' and 'mind extension' sensations experienced during the performance of specific religious activities, such as meditation, prayer, contemplation, etc. Similar sensations may also be elicited artificially, using pharmacological or psychedelic drugs. Hammer asked the question whether there were any natural chemical compounds generated in our brain that were similar to pharmacological substances generating or controlling specific states of consciousness? If so, which genes code such neurotransmitters? Together with George Uhl, neurobiologists from the National Institute of Drug Abuse, they focused their work on VMAT2 gene responsible for delaying the release of neurotransmitters (monoanimes) in synapses. According to the scholars, activity and an appropriate variant of this gene may be linked to intensity and duration of the sensation of 'onesness with the universe', experienced during religious activities [13].

The last group of studies includes experiments evoking specific states of consciousness using specific chemical substances. Psychoactive substances, occurring naturally in the human body, raise particular interest. Many of those compounds are also found in plants. Such psychedelic substances include DMT (dimetylotryptamine). Some ritual beverages (e.g. ayahuasca), used in numerous cultures or South America and Africa, include DMT-rich plant extracts or animal parts. Rick Strassman and colleagues performed an experiment consisting in injection of large doses of this psychedelic and found that $20 \%$ of volunteers participating in the study described their hallucinations as contact with non-human creatures. The researchers found that DMT-induced sensations may be identical to religious experiences [21].

\section{Context of Neurotheological Experiments}

For several decades, neurotheology has raised fierce discussions between supporters of naturalist concept of religion and mystics, between theists and atheists. Attempts to find evidence for faith being generated by specific brain structures or neurophysiological determinants are closely followed by scholars and the general audience. Some claim that the results of neurotheological experiments could disprove the belief in the existence of God, while others argue that they could sanction the phenomenon of religion and faith as resulting from biological foundations of human brain.

The question of whether religion is a natural phenomenon specific for humans is not a matter of recent decades. Already at the time of Darwin, people began to wonder whether religion may be the product of evolutionary transformations occurring in the course of human race development. Much earlier, already in the Antiquity, scholars pointed out to co-existence of specific states of increased brain activity and sensations classified as religious experience. Literature on the history of medicine includes treaties on religious states occurring in somatic or mental diseases, or 
after the application of hallucination inducing and psychedelic drugs [5], [6]. However, as late as in the $20^{\text {th }}$ century, attempts were made to find correlation between religious experiences and parametrised activity of human brain. This claims raised numerous objections and reservations, in particular among comparative religion experts.

Classic study of religion is based on two axes: diachronic and synchronic, supplemented by phenomenological and hermeneutic discourse. Along with the development of sciences, sociological, psychological and cultural anthropology discourses also appeared. In the second half of the 20th century, a new area of studies, called cognitive, appeared. The progress in natural and mathematical sciences led to the formation of new scientific disciplines, such as neurobiology, systems theory, information theory, linguistics, cognitive psychology, etc., allowing to initiate religious discourse of an unprecedented scope [20]. Research on biological determinants of religious behaviour started at the beginning of the $20^{\text {th }}$ century, when Oskar Goldberg described the impact of rituals on racial genetic, ethnogenetic and biological processes. In the 1960s J.S. Huxley investigated religious rituals in the context of their biological and evolutionary determinants. Similar considerations may be found in the work of ethologists, such as K. Lorentz and N. Tinbergen. In the following years, religious behaviours, in particular rituals, were analysed in the context of ecological, neuropsychological and evolutionary theories. It was found that religions share numerous similarities, e.g. rituals, behaviour, ideas. Widespread occurrence of religious life is also striking. Non-cultural similarities between religious phenomena are analysed using theological, phenomenological and cognitive approaches [22].

According to the theological approach, an explanation for similarity of religious phenomena may be the fact that they refer to transcendental reality. In the phenomenological interpretation, the essence of religious phenomena, which is common for all, is manifested in various religions in different ways. In line with the third approach, supracultural similarity of religious phenomena results from the uniqueness of human brain [22]. Supporters of the last approach assume that there are cognitive mechanisms or processes that may determine religious phenomena. Such mechanisms could explain the observed supra-cultural repeatability and universality of religious experience. Being specific for human brain, they would be responsible for surprising similarities of behaviour and phenomena in different religions. In view of such significant objectives, enthusiasts of the cognitive approach believe that religious phenomena can and should be investigated using the methods specific for cognitive sciences and neurosciences. The remaining problem is the selection of the analysed aspects. Cognitive approach is thus searching for answers to two important questions. First, why people have religion and second, why there are similarities in religious experience, its diversity and abundance [22]. Cognitive approach to the study of religion is also linked to an approach which uses evolutionary arguments. Therefore, religion may be treated as a mechanism of social involvement developed in the process of natural selection. It requires the analysis of the cognitive structure of human brain, in particular its evolution and influence on formation of religious engagement [3].

Attention must also be paid to the issue of recording the brain activity. Despite increasingly technologically advanced methods of analysing brain structure, little is still known on how their activity translates into specific behaviour. Moreover, even very thorough knowledge about the structure of a given nervous system does not allow to identify specific structures responsible for specific activities. It is clearly demonstrated in research on the behaviour of Caenorhabditis elegans. In 1986, its connectenome, i.e. a complete map of connections between its 302 nervous cells, was published. However, despite many years of research, scientists are unable to identify how those connections allow to perform specific actions, including such essential ones as eating. It remains unknown how neuronal impulses translate into behaviour. The interpretation of brain activity recordings becomes even more complicated in more complex organisms. Information obtained from brain scans illustrates the activity of individual brain regions, but does not mean that specific behaviour is generated by specific structures, and only signals that they are activated during a given action. Such discoveries, as the identification of the 'Aniston neuron', i.e. nervous cells responding only to specific forms of activity (e.g. a photo of actress Jennifer Aniston), still do not 
have any satisfactory explanations [17]. Therefore, calls are made to develop the methods allowing to monitor brain activity that would be superior to the currently used neuroimaging methods. Identification and description of specific patterns of neuronal activity within the widest possible scope could allow to obtain essential information on how specific behaviours, states of consciousness, etc. are generated [23].

The results obtained in neurotheological experiments thus far failed to provide explicit answers. Numerous studies were challenged due to their methods and the lack of methodological precision. Some experiments could not have been repeated, while in other cases the results differed considerably from the previous ones. Numerous articles are devoted to critical analysis of the performed studies, their assumptions, methodology and interpretation.

\section{4. (Over)Interpretation of Neurotheological Experiments}

Studies on correlation between brain activity and spirituality are thoroughly scrutinized. On the one hand, as in neurobiological sciences, the verified aspects include research procedures, selection of volunteers, conditions and course of procedures, research assumptions and hypotheses, methods of obtaining the analysed results, etc. On the other hand, specialists in theological sciences and comparative religion experts analyse the studies in detail from the point of view of their subject. When subject to such thorough analyses, neurotheological studies seem to provide too weak grounds for proposing arguments about neurobiological determinants of religion. It is worth looking at reservations formulated with respect to neurotheology.

The first group of reservations concern methodological, philosophical and theological aspects of research. The analysis of preassumptions of neurotheological studies justifies the claim that they most often focus on a specific type of religious experience, such as meditation or prayer. The decisive factor in those research is the experience intensity. It is due to possibilities of the applied neurobiological procedures resulting from the selected neuroimaging techniques or measured physiological parameters. In consequence, religion and faith are reduced to the selected religious experiences that are measured. However, the results are interpreted in the context of faith understood as broadly as possible and extrapolated to all religious doctrines [12, p. 51]. The complexity of religious experience is reduced to language, the sociological and ethnological connotations of which become the main motive of interpretation and blur the research results [12, $\mathrm{p}$. 62]. Attempts were also made to define universal supracultural elements of religious experience in the preassumptions, but with their simplified understanding this leads to unfounded and farreaching reductions (studies by Newberg et al. [14]).

Critics point out that the fundamental concept for neurotheological research is the common belief that religious phenomena are natural, which leads to disregarding the multidimensionality of religious experience and to simplification of complexity of religion and faith [7, p. 121]. It is also worth noting that numerous scholars try to distinguish between mystical and religious experience, adopting operational terms that are appropriate for individual research projects. In consequence, definitions of religious experience in neurotheology are imprecise and inconsistent.

Experts in religious and philosophical sciences also voice reservations about the language and methodology of neurotheology. They put forward accusations of unfounded extrapolation from neurobiological sciences to theological language and subject [12, p. 52]. Furthermore, theological language is used for describing psychosomatic sensations in research results. Therefore, claims are made that neurotheology lacks conceptual apparatus and methodology [7, p. 121].

Another controversial issue is the maximalist objective of neurotheology, which is to find the ultimate answer to the question of God's existence or non-existence, determined for research with a minimalist objective, which is to discover neurological or physiological correlates of religious experience [12, p. 53].

In addition, the analyses of results, the experiments themselves and research projects are ideologically oriented, which excludes the objectivity of interpretation. As a result, already in preassumptions, in the 'leftist' interpretation, faith is treated as the effect of electrical and chemical 
brain activity, whereas in the 'rightist' interpretation, the co-existence of brain activity and religious experience demonstrates that the transcendental aspect of faith is embedded in human nervous system [12, p. 53].

The second group of reservations refers to methods used in neurobiological studies. It concerns, first of all, research groups, their number and selection of volunteers. The latter are often persons from groups selected because of occurrence of specific disorders (e.g. in research by Ramachandran et al. [18] and Persinger et al. [15], [16], [19]). Some analyses rely on case studies, which precludes their application to the entire population [12, p. 58]. In other studies, groups are very small, which also makes extrapolation difficult. Another reservation concerns the lack of possibility to repeat the performed tests on groups of volunteers selected using different criteria, but the same procedure (e.g. studies by Granqvist et al. [9]). It is also argued that the sensations experienced by volunteers are influenced by the specific definition of research objectives and that the tests are often distorted, e.g. by the need to self-control the religious experience during the experiment (studies by Newberg et al. [14]).

Critics often point out that regardless of the adopted assumptions and the applied empirical methods, neurotheological studies are in fact studies visualising only the brain activity during specific states of consciousness. The causal-mechanistic model or the neurocomputational model used in neurobiological sciences is insufficient for neurotheological analyses [7, pp. 120-121]. Cognitive sciences are founded on models rooted in the synthetic theory of evolution, neurobiology, cognitive linguistics, cognitive psychology, etc., which seem inadequate when applied to religious sciences [20, p. XIII].

Another problem is the location of religious experience in the brain. According to some researchers it is related to a specific structure (studies by Persinger [15], [16], [19], Azari [2], Ramachandran et al. [18]). However, others argue that religious experience may be linked to activity of the entire brain (Newberg studies [14]). Therefore, preassumptions include the need to identify the physical location of such experience in brain structures, and to establish the scope of observations, which determines the interpretation of results.

\section{Final Remarks}

Neurotheology, contrary to expectations of numerous scholars, seems to be an interdisciplinary research programme or project that should not be treated as a scientific discipline on its own. As a research programme, it may inspire and encourage questions and new scientific challenges. The lack of a well-developed methodology, language and assumptions hampers the interpretation of results. Worldview determinants and context of research also lead to excessive extrapolations. It seems that the most adequate role for neurotheology is inspirational. It may thus be expected that questions and research proposals formulated by neurotheology proponents will contribute to better understanding of the basics of human brain functioning. However, finding the neurological correlates of faith seems as unattainable goal as explaining the mystery of life.

\section{References}

1. Ashbrook, J. Neurotheology: the working brain and the work of theology. Zygon, 19(3), 1984, pp. 331-50.

2. Azari, N. P., Nickel, J., Wunderlich, G., Niedeggen, M., Hefter, H., Tellmann, L., Herzog, H., Stoerig, P., Birnbacher, D., Seitz, R. Neural correlates of religious experience. European Journal of Neuroscience, 13, 2001, pp. 1649-1652.

3. Atran, S. Ewolucyjny krajobraz religii. Nomos: Kraków, 2013.

4. Beauregard, M., Paquette, V. Neural correlates of a mystical experience in Carmelite nuns. Neuroscience Letters, 405, 2006, pp. 186-190.

5. Błaszczyk, B. Święta choroba czyli historia padaczki. St. Med. Akademii Świętokrzyskiej. Vol. 1, 2003, pp. 209-212. 
6. Brzeziński, T. Historia medycyny. PZWL, 2014.

7. Dulewicz, M. Neuroteologiczne wyjaśnienia przeżyć religijnych. Analiza krytyczna. Humaniora. Czasopismo Internetowe, 2(2), 2013, pp. 113-121.

8. Fiałkowski, K., Bielicki, T. Homo przypadkiem Sapiens. PWN, 2008.

9. Granqvist, P., Fredrikson, M., Unge, P., Hagenfeldt, A., Valind, S., Larhammar, D., Larsson, M. Sensed presence and mystical experiences are predicted by suggestibility, not by the application of transcranial weak complex magnetic fields. Neuroscience Letters, 379 (1), 2005, pp. 1-6.

10. Hamer, D. The God Gene: How Faith Is Hardwired Into Our Genes. Doubleday: New York, 2004.

11. Jaubert, J., Verheyden, S., Genty, D., Soulier, M., Cheng, H., Blamart, D., Burlet, Ch., Camus, H., Delaby, S, Deldicque, D., Edwards, R. L., Ferrier, C., Lacrampe-Cuyaubère, F., Lévêque, F., Maksud, F, Mora, P., Muth, X., Régnier, É., Rouzaud, J.-N., Santos, F. Early Neanderthal constructions deep in Bruniquel Cave in southwestern France. Nature, 534, 02 June 2016, pp. 111114.

12. Kowalczyk, K. Neuroteologia - naturalistyczna konceptualizacja doświadczenia religijnego. Hybris, 17, 2012, pp. 50-79.

13. Muller, R. J. Neurotheology: Are We Hardwired for God?, 2008. http://www.psychiatrictimes.com/articles/neurotheology-are-we-hardwired-god/page/0/1;

[08/2016].

14. Newberg, A., D’Aquili, E., Rause, V. Why God Won't Go Away. Brain Science and the Biology of Belief. Ballantine Books: New York, 2002.

15. Persinger, M. A. Neuropsychological bases of God beliefs. Praeger: Westport, 1987.

16. Persinger, M. A. Religious and mystical experiences as artifacts of temporal lobe function: a general hypothesis. Perceptual and motor skills, 57 (3 Pt 2), 1983, pp. 1255-1262.

17. Quiroga, R. Q. Searching for the Jennifer Aniston Neuron. Scientific American, Vol. 308, Issue $2,2013$.

18. Ramachandran, V. S. Neuronauka o podstawach człowieczeństwa: O czym mówi mózg? Wydawnictwa Uniwersytetu Warszawskiego, 2012.

19. Ruttan, L. A., Persinger, M. A., Koren, S. Enhancement of Temporal Lobe-Related Experiences During Brief Exposures to MilliGauss Intensity Extremely Low Frequency Magnetic Fields. Journal of Bioelectricity, 9 (1), 1990, pp. 33-54.

20. Sikora, T. Przedmowa: Zagadnienia kognitywizmu religioznawczego. In. S. Atran. Ewolucyjny krajobraz religii. Nomos: Kraków, 2013.

21. Strassman, R. DMT: The Spirit Molecule: A Doctor's Revolutionary Research into the Biology of Near-Death and Mystical Experiences. Park Street Press, 2001.

22. Sztajer, S. Uniwersalia religijne a procesy poznawcze. Przeglad Religioznawczy, 1 (243), 2012, pp. 61-68.

23. Yuste, R., Church, G. M. Nowa era badań mózgu. Świat Nauki, 4 /2014. 